Việc tầm soát ban đầu nên được thực hiện đầy đủ các xét nghiệm theo như hướng dẫn của các hiệp hội về điều trị viêm gan $B$ để tránh bỏ sót nhóm đối tượng cần được dự phòng.

\section{TÀI LIÊUU THAM KHẢO}

1. EASL 2017 Clinical Practice Guidelines on the management of hepatitis $B$ virus infection. J Hepatol. 2017;67(2):370-398. doi:10.1016/ j.jhep.2017.03.021

2. Zhou $\mathbf{X}$, Wuchter $\mathbf{P}$, Egerer $\mathbf{G}$, et al. Role of virological serum markers in patients with both hepatitis $B$ virus infection and diffuse large B-cell lymphoma. Eur J Haematol. 2019;103(4):410-416. doi:10.1111/ejh.13300

3. Kim M, Lee YK, Park B, Oh DJ, Choi HG. Hepatitis virus $B$ and $C$ infections are associated with an increased risk of non-Hodgkin lymphoma: A nested case-control study using a national sample cohort. J Med Virol. 2020;92(8):1214-1220. doi:10.1002/jmv.25653

4. Zhou $X$, Wuchter $P$, Egerer $G$, et al. Serological hepatitis $B$ virus (HBV) activity in patients with HBV infection and B-cell non-Hodgkin's lymphoma. Eur ] Haematol. 2020;104(5):469-475. doi:10.1111/ ejh.13388

5. Meng J, Xu H, Sui $D$, et al. A retrospective serological survey of hepatitis B virus infection in Northeast China. BMC Infect Dis. 2019;19:440. doi:10.1186/s12879-019-4091-3

6. WHO | Guidelines for the prevention, care and treatment of persons with chronic hepatitis $B$ infection. WHO. Accessed May 15, 2020.

7. Tang $Z$, Li $\mathbf{X}$, Wu S, et al. Risk of hepatitis $B$ reactivation in HBsAg-negative/HBcAb-positive patients with undetectable serum HBV DNA after treatment with rituximab for lymphoma: a metaanalysis. Hepatol Int. 2017;11(5):429-433. doi:10.1007/s12072-017-9817-y

8. Bô̂ Y Tế. Hướng dẫn chẩn đoán và điều trị bệnh viểm gan vi rút $\mathrm{B}$. Published online 2019.

\title{
ĐĂC ĐIỂM LÂM SÀNG TRIỆU CHỨNG ĂN UỐNG Ở NGƯỜI BÊNH GIAI ĐOẠN TRẦM CẢM ĐIỀU TRI NộI TRÚ TẠI VIỆN SỨC KHỎE TÂM THẦN
}

\section{TÓM TẮT}

Trầm cảm là một rối loạn tâm thần phổ biến, mang lại gánh nặng bệnh tật nhiều nhất, gây tổn thất ang đâu về chi phí và thương vong. Trong đó biểu hiện về ăn uống thuộc nhóm triệu chứng sinh học rất thường gặp trong trẩm cảm, ảnh hưởng đến các triệu chứng quan trọng khác như giảm năng lượng hoạt động,

ang sự mệt mỏi và giảm sút trọng lượng cơ thể. Tại Việt Nam cho đến nay đã có nghiên cứu về đắc điểm lâm ang trầm cảm, tuy nhiên việc tiếp cậ̉n triệu chứng ăn uống của trầm cảm còn chưa có nhiều. Do đó, chúng tôi thực hiện nghiên cứu đề tài: "Đặc điểm lâm ang triệu chứng ăn uống ở người bệnh giai đoạn trầm cảm điều trị nội trú tại Viện Sức khỏe Tâm thần". Mục tiêu: "Mô tả đặc điểm lâm ang triệu chứng ăn uống ở người bệnh giai đoạn trầm cảm điểu trị nội trú tại Viện Sức khỏe Tâm thần". Đối tượng và phương pháp nghiên cứu: Nghiên cứu mô tả cắt ngang 68 bệnh nhân giai đoạn trầm cảm điều trị nội trú tại Viện Sức khỏe Tâm thần từ tháng 08/2020 đến tháng 05/2021. Kết quả: Đa phần người bệnh là nữ giới, chiếm 64,7\% tông số người bệnh, độ tuổi trung bình $40.01 \pm 15.79$, nơi sinh sống nhiều hơn ở nông thôn $(55,9 \%)$, trình độ học vấn trung học phổ ang $38.2 \%$. Về đặc điểm triệu chứng ăn uống: thời gian xuất hiện tỷ lệ cao nhẩt là cùng lúc với trầm cảm

\footnotetext{
${ }^{1}$ Đai họ Y Hà Nôi

${ }^{2}$ Viện Sức khoé Tâm thần Quốc gia, Bệnh viện Bạch Mai. Chịu trách nhiệm chính: Nguyễn Thu Hà

Email: hanguyenthu210@gmail.com

Ngày nhận bài: 2.8 .2021

Ngày phản biên khoa học: 30.9.2021

Ngày duyệt bài: 7.10.2021
}

\section{Nguyễn Thu Hà ${ }^{1}$, Trần Nguyễn Ngọc $\mathrm{c}^{1,2}$}

chiếm $63.2 \%$. Giảm cảm giác ngon miệng thường gặp nhất $48.5 \%$, mất cảm giác ngon miệng chiếm $25.0 \%$, ang cảm giác ngon miệng chiếm $11.8 \%$. Về đặc điểm về bữa ăn, ăn không đúng bữa (42.6\%); có $47.1 \%$ người bệnh ăn 3 bữa/ngày, 2 bữa/ngày (35.4\%), 1 bữa/ngày (4.4\%). Người bệnh ăn ít hơn chiếm tỷ lệ nhiêu hơn số người bệnh ăn nhiều hơn $(82.4 \%$ và $13.2 \%)$. Có đến $64,7 \%$ người bệnh có phong cách ăn uống không lành mạnh, trong đó tỷ lệ người bệnh ăn uống thất thường theo cảm xúc chiếm cao nhẩt là $50.0 \%$. Kết luận: Các triệu chứng ăn uống rất thường gặp ở giai đoạn trầm cảm. Vì vậy cân chú ý đến nhóm triệu chứng này để phát hiện và điều trị sớm để cải thiện tình trạng bệnh và nâng cao chất lượng cuộc sống của người bệnh.

Tư khóa: Trâm cảm, cảm giác ngon miệng, ăn uống.

\section{SUMMARY \\ CLINICAL CHARACTERISTICS OF EATING SYMPTOMS IN INPATIENTS WITH DEPRESSIVE EPISODE TREATED AT THE INSTITUTE OF MENTAL HEALTH}

Depression is a common mental disorder, causing the largest disease burden and losing costs and casualties. In particular, the expression of eating and drinking belongs to the group of biological symptoms common in depression, affecting other important symptoms such as psychomotor retardation, increased fatigue, and decreased body weight. In Vietnam, there have been studies on clinical features of depression; however, access to eating symptoms of depression is still not much. Therefore, we conducted a study on the topic: "Clinical characteristics of eating and drinking symptoms in patients with depressive episode inpatient treatment at the Institute of Mental Health". 
Objective: "Describe clinical characteristics eating symptoms in patients with depressive episode inpatient treatment at the Institute of Mental Health." Subjects and methods: A cross-sectional descriptive study of 68 depressive episodes inpatient treatment at the Institute of Mental Health from August 2020 to May 2021. Results: Most of the patients were female, accounting for $64.7 \%$ of the total number of patients, the average age was $40.01 \pm 15.79$, where they lived more than in the countryside $(55.9 \%)$, had a high school education. $38.2 \%$. Regarding the characteristics of eating symptoms: the time of occurrence of the highest rate was at the same time as depression, accounting for $63.2 \%$. Loss of appetite is most common $48.5 \%$, loss of appetite is $25.0 \%$, increased appetite is $11.8 \%$. Regarding the characteristics of meals, eating at the wrong time $(42.6 \%) ; 47.1 \%$ of patients ate 3 meals/day, 2 meals/day (35.4\%), 1 meal/day (4.4\%). Patients who ate less accounted for more than patients who ate more $(82.4 \%$ and $13.2 \%)$. Up to $64.7 \%$ of patients have an unhealthy eating style, in which the highest percentage of patients with emotional eating is $50.0 \%$. Conclusion: Eating symptoms are widespread in the depressive episode. Therefore, it is necessary to pay attention to this group of symptoms for early detection and treatment to improve the disease status and improve the patient's quality of life.

Keywords: Depression, appetite, eating.

\section{I. ĐĂT VẤN ĐỀ}

Trầm cảm là một rối loạn tâm thần phổ biến, là trạng thái bệnh lý cảm xúc gây ảnh hưởng lớn đến sức khỏe và chất lượng cuộc sống của người bệnh. Theo ước tính của Tổ chức Y tế thế giới năm 2017, có khoảng 322 triệu người mắc trầm cảm tương đương khoảng 4,4\% dân số thế giới ${ }^{1}$. Hiện nay ở Việt Nam, rối loạn trầm cảm được chẩn đoán theo Bảng phân loại bệnh quốc tế lần thứ 10 (ICD-10) bằng các nhóm triệu chứng chính, phổ biến, và cơ thể (sinh học). Trong đó biểu hiện về ăn uống thuộc nhóm triệu chứng sinh học rất thường gặp trong trầm cảm, ảnh hưởng đến các triệu chứng quan trọng khác như giảm năng lượng hoạt động, tăng sự mệt mỏi và giảm sút trọng lượng cớ thể, thậm chí dẫn đến suy kiệt và tử vong. Có nhiêu nghiên cứu ở Việt Nam về đặc điểm lâm sàng của trầm cảm, tuy nhiên chưa có nhiều nghiên cứu về vấn đề triệu chứng ăn uống. Vì vậy, với mong muốn nâng cao kiến thức để phục vụ cho mục đích chẩn đoán, điều trị và cải thiện chất lượng cuộc sống cho người bệnh, chúng tôi thực hiện nghiên cứu đề tài: "Đặc điểm lâm sàng triệu chứng ăn uống ở người bệnh giai đoạn trầm cảm điều trị nội trú tại Viện Sức khỏe Tâm thần" nhằm làm rõ vấn đề này.

II. ĐốI TƯợNG VÀ PHƯƠNG PHÁP NGHIÊN CứU
1. Đối tượng, địa điểm, thời gian nghiên cứu: 68 người bệnh được chẩn đoán giai đoạn trầm cảm điều trị nội trú tại Viện Sức khỏe Tâm thần từ tháng 08/2020 đến tháng 05/2021, với các mức độ nhẹ, vừa và nặng đáp ứng tiêu chuẩn chẩn đoán theo mã F32.xx của ICD - 10.

2. Phương pháp nghiên cứu: Phương pháp nghiên cứu mô tả cắt ngang

3. Phân tích, xử lí số liệu: Các số liệu được phân tích và xử lý bằng phần mềm SPSS 25.0

\section{KẾT QUẢ NGHIÊN CỨU}

\section{1 Đặc điểm chung của nhóm nghiên cứu}

Bảng 1: Đăc điểm chung về tuổi, giới, nơi sông, trinh độhọc vấn

\begin{tabular}{|c|c|c|c|}
\hline \multicolumn{2}{|r|}{ Đặc điểm } & $\begin{array}{c}\text { Số } \\
\text { lương }\end{array}$ & $\begin{array}{l}\text { Tỷ lệ } \\
\%\end{array}$ \\
\hline \multicolumn{2}{|r|}{ Tuối trung bình } & \multicolumn{2}{|c|}{$40.01 \pm 15.79$} \\
\hline \multirow[t]{2}{*}{ Giới } & Nam & 24 & 35.3 \\
\hline & Nữ & 44 & 64.7 \\
\hline \multirow{3}{*}{$\begin{array}{l}\text { Nơi sinh } \\
\text { sống }\end{array}$} & Nông thôn & 38 & 55.9 \\
\hline & Thành thị & 27 & 39.7 \\
\hline & Miền núi & 3 & 4.4 \\
\hline \multirow{5}{*}{$\begin{array}{c}\text { Trình } \\
\text { độ học } \\
\text { vấn }\end{array}$} & Không biết chữ & 1 & 1.5 \\
\hline & Tiếu học & 3 & 4.4 \\
\hline & Trung học cơ sở & 22 & 32.4 \\
\hline & Trung học phố thông & 26 & 38.2 \\
\hline & $\begin{array}{c}\text { Cao đằng, đại học, sau } \\
\text { đại học }\end{array}$ & 16 & 23.5 \\
\hline
\end{tabular}

Nhận xét: Tuối trung bình của nhóm người bênh nghiên cứu là $40.01 \pm 15.79$. Phần lớn người bểnh là nữ giới, chiếm $64.7 \%$. Kết quả nghiên cứu çủa chúng phù hợp với nghiên cứu của Nguyễn Trọng Hiến (2016): tỷ lệ người bệnh nữ cao hơn tỷ lệ người bệnh nam $(70,4 \%$ và $29,6 \%)^{2}$. Phần lớn người bệnh có trình độ học vấn trung học cơ sở và trung học phổ thông (70.8\%), tỷ lệ người bệnh sinh sống ở vùng nông thôn (55.9\%) nhiều hơn so với ở thành thị (39.7\%), sự khác biệt gợi ý Giai đoạn trầm cảm phổ biến ở những người có hoàn cảnh sống, điều kiện kinh tế thấp, sự nghèo nàn thiếu thốn liên quan trực tiếp đến tỷ lệ mắc rối loạn này.

3.2 Đặc điểm lâm sàng triệu chứng ăn uống ở người bênh giai đoan trâm cảm

3.2.1 Đăc điểm về bữa ăn

Bảng 2: Đặc điểm về bữa ăn

\begin{tabular}{|c|c|c|c|}
\hline \multicolumn{2}{|c|}{ Đăcc điểm } & $\begin{array}{c}\text { Số } \\
\text { lươna }\end{array}$ & $\begin{array}{l}\text { Tỷ lệ } \\
\%\end{array}$ \\
\hline \multicolumn{2}{|c|}{ Không có triệu chứng ăn uống } & 3 & 4.4 \\
\hline \multicolumn{2}{|c|}{ Có triệu chứng ăn uống } & 65 & 95.6 \\
\hline \multirow{3}{*}{$\begin{array}{l}\text { Thời gian } \\
\text { xuất hiện } \\
\text { triệu chứng } \\
\text { ăn uống }\end{array}$} & Trước trầm cảm & 6 & 8.8 \\
\hline & $\begin{array}{l}\text { Cùng lúc với } \\
\text { trầm cảm }\end{array}$ & 43 & 63.2 \\
\hline & Sau khi trầm cảm & 16 & 23.5 \\
\hline
\end{tabular}




\begin{tabular}{|c|c|c|c|}
\hline \multirow{4}{*}{$\begin{array}{l}\text { Số lượng } \\
\text { bữa } \\
\text { ăn/ngày }\end{array}$} & 1 bữa & 3 & 4.4 \\
\hline & 2 bữa & 24 & 35.4 \\
\hline & 3 bữa & 32 & 47.0 \\
\hline & $>3$ bữa & 9 & 13.2 \\
\hline \multirow{2}{*}{$\begin{array}{c}\text { Hoàn cảnh } \\
\text { bắt đâuu bữa } \\
\text { ăn }\end{array}$} & Àn đúng bữa & 29 & 42.6 \\
\hline & $\begin{array}{c}\text { Ān không đúng } \\
\text { bữa }\end{array}$ & 39 & 57.4 \\
\hline \multirow{2}{*}{$\begin{array}{c}\text { Thay đối } \\
\text { lượng thức } \\
\text { ăn ằn vào } \\
\text { mối bữa }\end{array}$} & Àn ít hơn & 56 & 82.4 \\
\hline & Ăn nhiều hơn & 9 & 13.2 \\
\hline
\end{tabular}

Nhận xét: Thời gian xuất hiện triệu chứng ăn uống thường gặp nhất là xuất hiện cùng lúc với trầm cảm (63.2\%), nhóm người bệnh xuất hiện sau khi mắc trầm cảm (23.5\%). Nghiên cứu của chúng tôi có sự tương đồng so với nghiên cứu của Nguyễn Văn Dũng (2015), người bệnh chán ăn ở giai đoạn sớm chiếm $61.9 \%{ }^{3}$, chủ yếu người bệnh xuất hiện và khởi phát các triệu chứng ăn uống ở trong giai đoạn của trầm cảm.

Đặc điểm hoàn cảnh bắt đầu bữa ăn ở nhóm người bệnh ăn đúng bữa $(57,4 \%)$ cao hơn so với nhóm người bệnh ăn không đúng bữa (42.6\%). Số lượng bữa ẳn trong ngày thường gặp nhất là nhóm người bệnh ăn 3 bữa/ngày (47.1\%), nhóm người bệnh ăn 2 bữa/ngày chiếm $35.4 \%$, và thấp nhất là 1 bữa/ngày $(4,4 \%)$.

Sự thay đổi về lượng thức ăn ăn vào mỗi bữa cho thấy số người bệnh ăn ít hơn chiếm tỷ lệ nhiều hơn số người bệnh ăn nhiều hơn $(82.4 \%$ và $13.2 \%)$. Trong số 68 người bệnh nghiên cứu có 65 người bệnh có triêu chứng ăn uống $(95.6 \%)$, chỉ có 3 người bệnh không có triệu chứng ăn uống, chiếm $4.4 \%$.

\begin{tabular}{|c|c|c|}
\hline $\begin{array}{c}\text { Sự thay đổi cảm giác } \\
\text { ngon miệng }\end{array}$ & $\begin{array}{c}\text { Số } \\
\text { lượng }\end{array}$ & $\begin{array}{c}\text { Tỷ lệ } \\
\text { \% }\end{array}$ \\
\hline Mất cảm giác & 17 & 25.0 \\
\hline Giảm cảm giác & 33 & 48.5 \\
\hline Không thay đổi & 10 & 14.7 \\
\hline Tăng cảm giác & 8 & 11.8 \\
\hline
\end{tabular}

Nhận xét: Kết quả nghiên cứu cho thây đa số người bệnh giảm và mất cảm giác ngon miệng (48.5\% và $25.0 \%)$, tỷ lệ người bệnh tăng cảm giác ngon miệng thấp nhất chiếm $11.8 \%$. Nghiên cứu của chúng tôi có sự tương đồng với kêt quả của Husain (2005) nghiên cứu trên các nhóm độ tuổi của người bệnh trầm cảm cho thấy giảm cảm giác ngon miệng chiếm tỷ lệ khoảng 44,2\% - 50,5\%, nhiều hớn so với tăng cảm giác ngon miêng $(20.3 \%-24.0 \%)^{4}$. Kết quả trên cho thây chủ yếu trong giai đoạn trầm cảm người bệnh phần lớn bị giảm cảm giác ngon miệng, tỷ lệ tắng ngon miệng chiếm số ít.

\subsection{3 Đặc điểm về phong cách ăn uống không lành mạnh trong giai đoạn trầm cảm Bảng 4: Đặc điểm về phong cách ăn uống không lảinh mạnh ở người bệnh giai đoạn} trầm cảm

\begin{tabular}{|c|c|c|c|c|c|c|}
\hline \multirow{2}{*}{$\begin{array}{c}\text { Phong cách ăn uống không } \\
\text { lành mạnh }\end{array}$} & \multicolumn{2}{|c|}{ Nam (SL=15) } & \multicolumn{2}{|c|}{ Nũ̃ $(S L=29)$} & \multicolumn{2}{|c|}{ Chung (SL=44) } \\
\hline & $\mathbf{S L}$ & $\%$ & $\mathbf{S L}$ & $\%$ & $\mathbf{S L}$ & $\%$ \\
\hline Ann uống thất thường theo cảm xúc & 5 & 33.3 & 17 & 58.6 & 22 & $\mathbf{5 0 . 0}$ \\
\hline Ãn uống ngọt nhiều hơn & 1 & 6.7 & 9 & 31.0 & 10 & 22.7 \\
\hline Àn thức ăn nhanh nhiều hơn & 3 & 20.0 & 3 & 10.3 & 6 & 13.6 \\
\hline Àn thức ăn chiên rán nhiều hơn & 3 & 20.0 & 1 & 3.4 & 4 & 9.1 \\
\hline Àn mặn nhiều hơn & 2 & 13.3 & 5 & 17.2 & 7 & 15.9 \\
\hline Uống rượu nhiều hơn & 1 & 6.7 & 0 & 0.0 & 1 & 2.3 \\
\hline
\end{tabular}

Nhận xét: Có đến 64,7\% người bệnh báo cáo có phong cách ăn uống không lành mạnh, trong đó quả nhóm người bệnh ăn uống thất thường theo cảm xúc chiếm tỷ lệ cao nhất là $50 \%$, nhóm người bệnh ăn uống ngọt nhiều hơn và ăn mặn nhiều hơn $(22.7 \%$ và $15,9 \%)$. Nhóm người bệnh nữ ăn uống thất thường theo cảm xúc và ăn nhiều ngọt hơn chiếm tỷ lệ $58,6 \%$ và $33.3 \%$; cao hơn so với nhóm người bệnh nam $31.0 \%$ và $6,7 \%$.

Nghiên cứu của Irina Lazarevich và cộng sự tại Mexico (2018) cho tỷ lệ đáng kể các sinh viên mắc trầm cảm báo cáo về thói quen ăn uống không lành mạnh: thường xuyên tiêu thụ thực phẩm chiên rán 30,3\%, đồ uống ngọt 49,9\%, thực phẩm có đường $51,8 \%$. Ở sinh viên nữ, trầm cảm có liên quan tiêu thụ đồ ăn nhanh cao hơn gấp 2,08 lần, thực phẩm chiên gấp 1,92 lần, thực phẩm có đường 2,16 lần ${ }^{5}$. Cho thây nhóm người bệnh nữ giới dễ sử dụng thực phẩm để đối phó với các cảm xúc tiêu cực hớn so với nam giới.

\section{KẾT LUÂ̂N}

Tỷ lệ người bệnh có triệu chứng ăn uống là $95.6 \%$. Thời gian xuất hiện triệu chứng ăn uống thường gặp nhất là xuất hiện cùng lúc với trầm cảm (63.2\%). Đặc điểm về bữa ăn của người bệnh cho thấy, ăn không đúng bữa (42.6\%); số lượng bữa ăn trong ngày có $47.1 \%$ người bệnh 
ăn 3 bữa/ngày, 2 bữa/ngày (35.4\%), 1 bữa/ngày (4.4\%). Người bênh ăn ít hơn chiếm tỷ lệ nhiều hơn số người bệnh ăn nhiều hơn $(82.4 \%$ và $13.2 \%)$. Chủ yếu trong giai đoạn trầm cảm người bệnh phần lớn bị giảm và mất cảm giác ngon miệng, tỷ lệ tăng ngon miệng chiếm số ít. Có đến 64,7\% người bệnh có phong cách ăn uống không lành manh, trong đó tỷ lệ người bệnh ăn uống thất thường theo cảm xúc chiếm cao nhất là $50.0 \%$. Vì vâyy, các triệu chứng ăn uống rất thường gặp ở giai đoạn trầm cảm. Cần chú ý đến nhóm triệu chứng này để phát hiện và điêu trị sớm để cải thiện tình trạng bệnh và nâng cao chất lượng cuộc sống của người bệnh.

\section{TÀI LIÊU THAM KHẢO}

1. World Health Organization. MSD-MER. Depression and other common Mental disorders: Global Health Estimates; 2017.2

2. Nguyễn Trọng Hiến. Nghiên Cứu Đặc Điểm Đau ở Bênh Nhân Rối Loan Trâm Cảm Điều Trị Nội Trú Tai Viện Sức Khỏe Tầm Thần. Luận văn tổt nghiệp Bác sỹ̃ Nội trú. Đại học Y Hà Nội; 2016.

3. Nguyễn Văn Dũ̉ng. Nghiên Cứu Đặc Điểm Lâm Sàng Trầm Cảm Khới Phát ở Người Cảo Tuổi. Luận án Tiến sỹ Y hoc; 2013.

4. Husain MM, Rush AJ, Sackeim HA, et al. Agerelated characteristics of depression: a preliminary STAR*D report. Am J Geriatr Psychiatry Off J Am Assoc Geriatr Psychiatry. 2005;13(10):852-860. doi:10.1176/appi.ajgp.13.10.852

5. Lazarevich I. Depression and food consumption in Mexican college students. Nutr Hosp. Published online May 10, 2018. doi:10.20960/nh.1500

\section{ĐÁNH GIÁ KẾT QUẢ ĐIỀU TRI VÀ MộT Số YẾU TỐ LIÊN QUAN TRÊN BỆNH NHÂN UNG THƯ TỤY GIAI ĐOẠN MUQ̣̂N TẠI BỆNH VIỆN K}

\section{TÓM TẮT}

Mục tiêu: Đánh giá kết quả điều trị và một số yếu tố liên quan trên bệnh nhân ung thư tụy giai đoạn muộn tại Bệnh viện K. Đối tượng: 154 bệnh nhẩn được chẩn đoán ung thư biểu mô tụy giai đoạn tiến triển tại chố hoặc di căn xa được chia làm 3 nhóm: điều trị hóa chất có thể kèm theo phẫu thuật hoặc can thiệp thủ thuật chăm sóc giảm nhẹ; nhóm không điều trị hóa chất được phẫu thuật, can thiệp CSGN và nhóm không điêu trị tại bệnh viện K. Kết quả: Trong nhóm 38 bệnh nhân không điều trị có trung vị thời gian sống thêm toàn bộ là 3.3 tháng (khoảng tin cậy 95\% là 2.9-3.7 tháng). Trong 22 bệnh nhân không điều trị hóa chất được phẫu thuật, can thiệp CSGN có trung vị thời gian sống thêm toàn bộ là 3.9 tháng (khoảng tin cậy 95\% là 3.1-4.8 tháng). Trong 94 bệnh nhân có điều trị hóa chất: Không có đáp ứng hoàn toàn và tỉ lệ đáp ứng 1 phần là $17 \%$, bệnh giữ nguyên là $37.2 \%$, bệnh tiến triên là $45.7 \%$. Trung vị thời gian sống thêm bệnh không tiến triển là 3.9 tháng (khoảng tin cậy $95 \%$ là 3.3-4.5 tháng). Trung vị thời gian sống thêm toàn bộ là 8.2 tháng (khoảng tin cậy $95 \%$ là $6.5-$ 9.8 tháng). Tổng số chu kì hóa chất được điều tri ở 94 bệnh nhân trong nghiên cứu là 381 chu kì. Về độc tính hóa chất: $\mathrm{Ha}$ bach cầu trung tính độ 3-4 gặp ở 10.2\% số bệnh nhân. Hạ tiểu cầu độ 3-4 gặp ở 6.9\% số bệnh nhân. Ha huyết sắc tố độ 3-4 gặp ở 7.6\% số bệnh

\footnotetext{
${ }^{1}$ Trường Đại học Y Hà Nội

2Bệnh viện $K$ trung ương

Chiu trách nhiệm chính: Hoàng Minh Lý

Email: hoangminhly3107@gmail.com

Ngày nhân bài: 3.8.2021

Ngày phản biện khoa học: 1.10.2021

Ngày duyệt bài: 7.10.2021
}

\section{Hoàng Minh Lý ${ }^{1}$, Đào Văn Tú ${ }^{2}$}

nhân. Tăng men gan độ 3 gặp ở 4.2\% số bệnh nhân. Không ghi nhận tăng men gan độ 4 .

Tư khóa: Ung thư tụy, Phẫu thuật/thủ thuật chăm sóc giảm nhẹ, Thời gian sống thêm bệnh khổng tiến triển, Thời gian sống thêm toàn bộ.

\section{SUMMARY}

\section{THE EFFICACY OF TREATMENT IN STAGE} III AND IV AND SOME FACTORS RELATED WITH THE PANCREATIC CANCER AT K HOSPITAL

Objectives: To evaluate the efficacy of treatment in stage III, IV and some factors related with the pancreatic cancer at $\mathrm{K}$ hospital. Patients and methods: 154 patients diagnosed with locally advanced or metastatic pancreatic cancer at K hospital were divided into 3 groups: chemotherapy group may be accompanied by palliative surgical procedures; the non-chemotherapy group received palliative surgical procedures; and untreated patients' group. Result: In the group of 38 untreated patients, the median overall survival was 3.3 months (95\% confidence interval 2.9 to 3.7 months). In 22 non-chemotherapy patients who underwent Palliative surgical procedures had a median overall survival of 3.9 months (95\% CI 3.1-4.8 months). In 94 patients receiving chemotherapy: We found that none of patient showed a complete response, the partial response rate was $17 \%, 37.2 \%$ of the patients were stable and $45.7 \%$ of the patients had progressive disease. The median progression-free survival was 3.9 months (95\% confidence interval, 3.3 to 4.5 months). The median overall survival was 8.2 months (95\% confidence interval, 6.5 to 9.8 months). Three hundred ninety-one cycles were administered with 154 patients, grade 3-4 toxicity per patient was $10.2 \%$ for neutropenia, $6.9 \%$ for thrombocytopenia, $7.6 \%$ for hematological toxicities, $6.9 \%$ for anemia. 